\title{
Usulan Manajemen Pengunjung Situs Makam Sunan Kalijaga, Kelurahan Kadilangu, Kabupaten Demak
}

\author{
Musadad \\ Pos-el: musadad.fib@ugm.ac.id \\ Tim Pengabdian kepada Masyarakat: \\ Musadad dan Nindi Jawining Aji
}

\begin{abstract}
The Sunan Kalijaga tomb complex located in Kadilangu, Demak, Central Java is an archaeological site that have very high significance values in terms of history, culture, and economy. This tomb complex is always fully-visited by pilgrims from various regions. The peak season of the tomb visiting period is in the month of Syafar, one month before Ramadan. At the time, the visitors must be trapped in a long queue in the corridor that was prepared by Yayasan Sunan Kalijaga to enter the tomb complex. This condition certainly leads inconveniences for pilgrims and it may decrease the site's significance values. For this reason, efforts are needed to reduce pilgrimage density in the corridors of pilgrims from the entrance gate to the site complex. Alternative proposals to reduce pilgrim density are proposed in two alternatives. The first, after the pilgrimage procession reaches and finishes their pilgrimage, the visitors should go out through another door and pass the south corridor of the mosque to the road on the east side of the mosque heading south to the ancient lake and heading to the road to the parking lot. The second proposal is that pilgrims passes through the existing corridor to enter and to exit, but the corridor is divided into two lanes in firm and very strict arrangements. This means that pilgrims should not enter the wrong lane and there are restrictions on the amount of entry at a time of high density.
\end{abstract}

Keywords: Sunan Kalijaga cemetery complex, visitor management, visitor flow planning, heritage values

\begin{abstract}
Abstrak
Kompleks makam Sunan Kalijaga yang berada di Kadilangu, Demak, Jawa Tengah merupakan situs tinggalan arkeologis yang bernilai sangat tinggi, baik dari sisi sejarah, kebudayaan, maupun ekonomi. Kompleks makam ini selalu ramai dikunjungi oleh peziarah dari berbagai daerah. Puncak kunjungan peziarah adalah pada bulan Syafar, yakni satu bulan sebelum bulan Ramadan. Pada masa puncak kunjungan peziarah, koridor untuk masuk yang dibuat secara resmi oleh Yayasan Sunan Kalijaga sangat padat hingga menimbulkan kemacetan perjalanan peziarah.

Kondisi seperti ini dapat menjadikan peziarah merasa kurang nyaman dan dimungkinkan akan dapat mendorong degradasi nilai lingkungan situs. Oleh karena itu, diperlukan upaya untuk mengurangi kepadatan peziarah pada koridor peziarah dari gerbang masuk menuju ke kompleks situs. Terdapat beberapa alternatif usulan untuk mengurangi kepadatan peziarah. Pertama, peziarah masuk melalui koridor yang sudah tersedia sekarang. Setelah prosesi ziarah selesai, pengunjung keluar melalui pintu lain dan melewati koridor sebelah selatan masjid menuju jalan di sisi timur masjid menuju ke selatan sampai ke telaga kuno dan menuju ke jalan
\end{abstract}


menuju parkiran kendaraan. Kedua, peziarah melewati koridor yang sekarang ada untuk masuk dan keluar, tetapi dengan pemisahan koridor menjadi dua secara tegas dan pengaturan yang sangat ketat. Artinya, peziarah tidak diperkenankan masuk pada jalur yang salah dan terdapat pengaturan pembatasan jumlah yang masuk pada waktu kepadatan tinggi.

Kata Kunci: Makam Sunan Kalijaga, pengelolaan pengunjung, perencanaan aliran pengunjung, peziarah, nilai penting cagar budaya

\section{Pendahuluan}

Kelurahan Kadilangu identik dengan tokoh Sunan Kalijaga sebagai salah satu anggota wali sanga pada masa lalu dan pada saat ini. Secara sosio-kultural, masyarakat masih tetap memandang makam dan masjidnya sebagai salah satu pusat kultural di Demak, selain Masjid Agung Demak. Bangunan makam dan lingkungannya dalam ingatan kolektif masyarakat merupakan pusat perjuangan Sunan Kalijaga yang sangat melegenda. Identitas karakter situs makam, masjid, telaga, dan lingkungannya membentuk kawasan budaya yang tidak lekang dimakan zaman dengan karakter budaya Jawa yang sangat kuat. Hal ini dibuktikan dengan kehadiran peziarah yang selalu berdatangan setiap hari, bahkan pada bulan-bulan tertentu sangat padat, seperti menjelang bulan Ramadan (bulan Ruwah). Apalagi pada saat prosesi jamasan pusaka Sunan Kalijaga, dapat dipastikan wisatawan yang hadir sangat banyak.

Kelurahan Kadilangu saat ini ditinggali oleh masyarakat dari berbagai profesi, baik masyarakat yang menetap maupun tinggal sementara untuk berdagang. Masyarakat yang tinggal di Kelurahan Kadilangu merupakan keturunan Sunan Kalijaga dari generasi ke generasi. Dewasa ini, dengan kehidupan yang semakin kompleks, di Kelurahan Kadilangu timbul berbagai persoalan, mulai dari persoalan sosial atau fisik yang berhubungan dengan status tanah dan bangunan yang ada di atasnya. Status tanah dan bangunan, perlahan tapi pasti, mulai berubah sesuasi dengan selera pemiliknya ataupun karena dorongan kebutuhan dengan berbagai alasan untuk membangun yang terus meningkat. Faktor ekonomi merupakan penyokong terkuat perubahan tataguna lahan karena hampir setiap jengkal tanah yang dekat dengan situs makam dan masjid merupakan aset ekonomi yang tinggi. Di atas tanah dekat situs adalah lokasi yang paling kental dengan transaksi ekonomi karena merupakan tempat berkerumunnya peziarah. Akibatnya, banyak lahan yang mungkin dahulunya merupakan bagian dari pusat kegiatan Sunan Kalijaga menjadi terganggu atau dialihfungsikan sebagai pembangunan fasilitas baru. Area ini menjadi sumber perekonomian Kelurahan Kadilangu sehingga oleh pemerintah setempat dibuat kelompok-kelompok pedagang, baik yang menempati area terbangun maupun area kaki lima.

Geliat pariwisata di tempat ini tidak dapat disalahkan karena merupakan sebuah kenyataan bahwa di manapun jika terdapat tokoh agama atau kultural dimakamkan, sangat mungkin terjadi kegiatan ziarah, baik sebagai kegiatan ibadah maupun wisata religi semata. Multiplier effect akan mengikuti seiring dengan tumbuhnya pariwisata di suatu tempat. Kelebihan dan kekurangan terhadap pandangan aktivitas wisata pun muncul. Geliat ekonomi bagi warga lokal akan mengikuti tumbuh dan berkembangnya wisata yang ada. Akan tetapi, tidak dapat dimungkiri bahwa masalah sosial pun dapat muncul sebagai akibat pertumbuhan ekonomi yang ada. Permasalahan yang muncul di antaranya 
adalah alih fungsi ruang terbuka atau bangunan yang terjadi demi mengejar keperluan pariwisata. Hal itu merupakan salah satu dampak negatif dari adanya pariwisata.

Bangunan cagar budaya dan situs di tempat ini cukup perlu dikhawatirkan karena menghadapi kuatnya tekanan pembangunan yang baru. Pada kenyataannya, bangunanbangunan cagar budaya ini merupakan aset daerah dan nasional sebagai warisan budaya bangsa. Bangunan cagar budaya ini merupakan peninggalan bersejarah yang memiliki nilai historis dan sosial serta nilai ekonomi sebagai sebuah investasi ke depan bagi kesejahteraan masyarakat. Oleh karena itu, diperlukan suatu perangkat strategis agar perlindungannya dapat diatur dan kelayakannya dapat ditata sebagai bangunan cagar budaya yang merupakan kekayaan karya intelektual di bidang seni cipta bangunan yang bernilai tinggi. Hal ini diperlukan untuk menjamin kelestarian bangunan cagar budaya tersebut sebagai warisan budaya masa lalu dalam kerangka pembangunan kebudayaan yang berkelanjutan.

Untuk memasuki area makam Sunan Kalijaga dan keluarganya, oleh Yayasan Sunan Kalijaga dibuatkan koridor jalan bagi peziarah. Koridor di sebelah selatan situs yang ada saat ini sudah cukup untuk melindungi pengunjung dari sinar matahari dan hujan. Akan tetapi, saat pengunjung yang hadir cukup banyak, hal itu menjadi agak berbahaya karena pengunjung dapat berpapasan dalam dua arah. Sementara itu, pada sebelah kanan-kiri koridor berderet kios-kios penjual, bahkan sudah ada pula penjual yang masuk ke koridor.

Berdasarkan latar belakang tersebut, muncul permasalahan yang berkaitan dengan pengaturan pengunjung sehingga diperlukan adanya manajemen pengunjung dengan tujuan agar situs Makam Sunan Kalijaga tetap aman dan membuat pengunjung merasa nyaman saat berziarah. Artinya, kelestarian situs makam tetap terjaga dengan nilai-nilai kesakralannya, sementara dari sisi pengunjung dapat tercapai sebuah perjalanan ziarah yang nyaman.

\section{Desain Program}

Kegiatan ini diawali dengan tahap observasi pada situs Makam Sunan Kalijaga dan lingkungannya. Observasi ini bertujuan untuk menyiapkan strategi manajemen pengunjung yang paling tepat pada sasaran kelestarian situs dan kenyamanan pengunjung. Observasi difokuskan pada pengamatan terhadap aliran pengunjung dan jalan yang dilalui karena permasalahan manajemen pengunjung di situs Makam Sunan Kalijaga terletak pada pengaturan pengunjung. Berdasarkan pengamatan tersebut, dibuat sebuah model alternatif rute pengunjung yang akan direkomendasikan kepada pengelola situs sebagai salah satu cara yang efektif dalam mengimplementasikan manajemen pengunjung yang baik.

\section{Hasil Observasi: Lingkungan Situs}

Dari kehidupan kultural yang ada, tidaklah mustahil bila perlakuan terhadap makam Sunan Kalijaga mempunyai keunikan tersendiri. Perlakuan ini pun dianggap sangat wajar oleh masyarakat yang kini menjadikan makam tersebut menjadi objek ziarah. Kedatangan mereka untuk berziarah didasari oleh kepercayaan bahwa tokoh ini sebagai 
pembawa Islam di tanah Jawa dan juga sebagai guru yang perlu mendapat penghormatan walaupun sudah meninggal. Hubungan antaranggota keturunan Sunan Kalijaga masih sangat kuat sehingga mereka menempati area sekitar situs sebagai bentuk keterikatan. Setelah Sunan Kalijaga wafat, penguasaan tanah Kadilangu beralih kepada anak cucunya secara turun-temurun sampai keturunan ketujuh dengan gelar "Panembahan". Mulai keturunan kedelapan sampai keturunan kedua belas, gelar yang diberikan "Pangeran Wijil". Pangeran Wijil yang terakhir meninggal dunia pada 11 Oktober 1880 (Surat Residen Semarang No. 11338/1 tanggal 22 Desember 1880 kepada Gubemur Jenderal Hindia Belanda).

Lingkungan sosial di sekitar makam sekarang didomiansi oleh pedagang yang menempati area sekitar situs yang memadati sampai ke pinggiran jalan. Pemerintah setempat mengatur pedagang-pedagang ini dalam bentuk kelompok-kelompok. Adanya pedagang-pedagang ini menjadikan perputaran ekonomi di Kelurahan Kadilangu bejalan lancar. Sementara itu, di sisi lain keberadaan pedagang-pedagang ini cukup perlu dikhawatirkan karena dapat menganggu kelestarian situs. Hal ini terlihat dari mulai tidak patuhnya beberapa pedagang yang masuk ke koridor jalan pengunjung.

Salah satu aspek lingkungan yang perlu diperhatikan adalah kondisi fisik sarana prasarana dengan memperhatikan tata letak dan fungsi-fungsi lain seperti sosial, kebudayaan, dan ekonomi. Keterkaitan visual adalah ikatan yang terjadi antara satu bangunan dan bangunan lain, jalan, serta ruang di dalam suatu kawasan yang secara visual menimbulkan citra tertentu terhadap kawasan tersebut. Citra yang terkandung dalam suatu kawasan dibentuk oleh bentuk, tatanan, dan suasana (Tim Peneliti, 2000:78). Situs dan lingkungannya menjadi faktor yang paling utama. Ikatan simbolik merupakan suatu gambaran nonvisual atau sesuatu yang lebih bersifat konsepsi simbolik. Hubungan sumbolik dalam suatu kawasan dapat memberikan kesan atau makna yang kuat terhadap keseluruhan kerangka kawasan karena adanya keterkaitan yang erat antara bentuk visual dan hubungan simbolik. Dari sudut pandang aspek budaya, hubungan simbolik menyangkut elemen bangunan yang dapat menggambarkan karakter budaya yang khas dan dapat menjadi ciri kawasan. Pengamatan ini dilakukan dengan tujuan mendapatkan potensi dan permasalahan dari sarana dan prasarana, khususnya aspek aksesibilitas, mengingat kawasan tersebut menjadi tempat yang sangat menjanjikan sebagai pusat perekonomian karena banyaknya peziarah yang datang. Dengan harapan, hasilnya dapat memberikan arahan dan pola penataan untuk mendukung kelestarian situs. Bangunan baru sebagai ruang layanan peziarah sebaiknya didirikan di luar area situs yang dibatasi oleh pagar keliling. Koridor jalan dari terminal kendaraan menuju situs dan masjid sudah cukup mendukung pelayanan untuk pengunjung. Permasalahan yang muncul adalah banyaknya pedagang yang memenuhi area luar situs sepanjang koridor sehingga area situs tidak terlihat dari jalan, bahkan bentuk area luar situs ini sudah seperti pasar.

Unsur lansekap berupa pohon atau tanaman peneduh serta tanaman hias tidak diperhatikan sama sekali di luar lingkungan situs. Keadaan ini merupakan akibat dari terlalu padatnya penjual yang menutupi area sepanjang koridor masuk. Tanaman jenis lokal berupa jambu air yang menunjang karakter situs perlu mendapat perhatian serius. Artinya, pengadaan tanaman ini akan mendukung filosofi situs makam yang dahulu berfigur sebagai guru dan pengayom masyarakat yang melegenda. Jangan sampai karakter 
ini hilang hanya karena terdesak oleh aktivitas ekonomi. Ruang terbuka diarahkan agar dapat menyerap air hujan dengan upaya penanaman rumput pada tanah kosong yang ada.

\section{Jenis dan Kondisi Cagar Budaya Serta Noncagar Budaya}

Situs makam Sunan Kalijaga dibatasi oleh pagar keliling dan di sisi timur terdapat masjid kuno yang sudah direnovasi. Bukti kekunoan masjid ini diperoleh dari data prasasti yang berada di atas ambang pintu, yang berbunyi menika titi mangsa ngadekipun masjid ngadilangu hing dino Ahad Wage 16 sasi Dzulhijjah tarikh Jawi 1456 atau "ini waktu dibangunnya Masjid Kadilangu pada hari Ahad Wage tanggal 16 Bulan Dzulhijjah tahun 1456 Jawa" atau tahun 1534 M. Makam inti di kompleks makam Sunan Kalijaga sudah ditutup dengan cungkup baru pada masa Presiden Soekarno, yakni sekitar 1963-1964. Di dalam cungkup makam inti terdapat makam istri Sunan Kalijaga dan putra-putri beliau, yaitu Panembahan Hadi, Ratu Retno Pembayun, Ratu Penenggak, dan Raden Abdurrachman. Di dalam cungkup ini juga dimakamkan adik Sunan Kalijaga, Dewi Rasa Eulan, dan ayah Sunan Kalijaga, Raden Tumenggung Wilatikta. Pada Jumat Pon, Jumat Kliwon, dan Jumat Pahing, cungkup ini dibuka untuk umum mulai pukul 08.00 - 17.00. Di sekitar makam inti terdapat makam-makam keturunan Sunan Kalijaga seperti makam Pangeran Wijil V (cucu Sunan Kalijaga) dan juga makam-makam baru yang semuanya merupakan keturunan dari Sunan Kalijaga, yang artinya bukan merupakan pemakaman umum. Kondisi makam Sunan Kalijaga sangat terawat dan diberi penutup kain putih. Benda cagar budaya lain yang memiliki jejak kehidupan Sunan Kalijaga adalah sepasang gentong yang saat ini masih difungsikan untuk tempat minum peziarah dengan peresediaan air suling dari sungai. Di luar situs, yakni sekitar $200 \mathrm{~m}$ dari situs, terdapat Gedung Pangeran Wijil V yang saat ini ditempati sebagai kantor sekretariat Yayasan Sunan Kalijaga. Di seberang rumah kepangeranan terdapat telaga yang di tengahnya ditanami pohon beringin besar. Oleh masyarakat setempat, telaga ini dianggap sebagai tinggalan dari Sunan Kalijaga. Agak jauh dari situs terdapat Gedung Notobratan yang merupakan bangunan tua dan saat ini menjadi kantor Kasepuhan.

Pusaka Sunan Kalijaga masih dirawat dengan baik, yakni seperti baju antakusumah, tasbih, keris Kyai Crubuk, keris Kyai Sirikan, dan tongkat kalimusada yang selalu di-jamasi (dibersihkan) pada 10 Dzulhijjah dengan perayaan besar yang melibatkan berbagai lapisan masyarakat. Perayaan ini juga dibarengi dengan grebeg besar sebagai bentuk penghormatan terhadap bulan haji.

Bangunan-bangunan noncagar budaya yang didirikan di dalam situs antara lain bangunan peristirahatan peziarah dan bangunan untuk pendaftaran tamu. Bangunanbangunan di sekitar situs yang bukan merupakan bangunan cagar budaya adalah sekolahsekolah, mulai dari TK sampai Aliyah yang didirikan oleh Yayasan. Bangunan yang paling mendominasi adalah toko-toko makanan dan suvenir yang berjajar sepanjang jalan kendaraan dan sepanjang koridor untuk menuju makam serta masjid.

\section{Organisasi Pengelola dan Masyarakat}

Situs Makam Sunan Kalijaga memiliki dua pengelola, yaitu Kasepuhan dan Yayasan Sunan Kalijaga. Kasepuhan merupakan institusi awal sebagai pengelola situs yang mewadahi 
Keturunan Sunan Kalijaga. Pada 19 Februari 1999, Kasepuhan mengalami perpecahan dengan didirikannya Yayasan Sunan Kalijaga sebagai bentuk ketidakpuasan terhadap institusi Kasepuhan. Pemisahan ini sangat disayangkan karena akan memengaruhi soliditas keturunan sebagai pemilik langsung situs makam Sunan Kalijaga.

Pihak Kelurahan juga mempunyai andil dalam pengelolaan situs makam ini. Mereka lebih berperan dalam pengaturan pedagang-pedagang dalam bentuk paguyubanpaguyuban yang berjumlah tujuh paguyuban. Koordinasi antarpaguyuban ini berada di pihak kelurahan. Sejak 2010 muncul perencanaan program seperti pengecoran jalan raya, pembuatan pintu gerbang, pembangunan museum, dan gedung kesenian. Retribusi parkir dan peziarah diatur oleh Dinas Pariwisata dan Kebudayaan. Selain itu, melalui APBD, Dinas Pariwisata dan Kebudayaan bekerja sama dengan ketakmiran Masjid Sunan Kalijaga dalam membangun fasilitas-fasilitas fisik. Pendapatan retribusi parkir dibagi menjadi dua, yakni sebanyak 50\% masuk ke pemangku situs makam dan 50\% masuk ke dinas.

\section{Nilai Penting Situs Makam}

Untuk penentuan nilai penting area Situs Makam Sunan Kalijaga, digunakan kriteria nilai penting dalam Undang-Undang Cagar Budaya, yakni sebagai berikut.

1. Nilai Penting Sejarah

Sebagai bagian dari sebuah pemukiman, area pemakaman dan masjid Sunan Kalijaga dibuat dengan perhitungan yang cermat dari berbagai segi. Makam dan masjid keberadaannya tidak dapat dilepaskan dari peran Sunan Kalijaga. Peran Sunan Kalijaga sebagai arsitek dan ulama dari Kerajaan Demak sangat besar sehingga diberi hadiah tanah di Kadilangu. Di situlah Sunan Kalijaga menunjukkan eksistensinya sebagai penguasa wilayah keulamaannya. Di situlah terdapat suatu penggalan peristiwa sejarah yang tidak dapat dilupakan dalam sejarah kewalian di Jawa karena merupakan suatu rangkaian sejarah yang tidak dapat dipisahkan dari pendirian wilayah kewalian yang lain. Sebagai seorang wali ketokohan, Sunan Kalijaga sangat fenomenal sehingga masyarakat di Jawa sampai saat ini masih melakukan ziarah ke makamnya. Adanya sengkalan (puniko titimangsa ngadegipun masjid kadilangu dinten ahad wage tanggal 16 sasi dulkijah tahun hijriyah alip tahun 1456/1534 T.U.) sebagai bukti pendirian masjid di atas ambang pintu utama ruang utama Masjid Kadilangu menjadi catatan yang sangat penting dan sebagai bagian dari perjuangan Sunan Kalijaga.

2. Nilai Penting Kebudayaan

Sampai saat ini, masyarakat masih mempunyai hubungan emosional yang sangat kuat dengan situs makam Sunan Kalijaga. Mereka masih menganggap bahwa tanah-tanah di Kadilangu merupakan milik keturunan Sunan Kalijaga. Bukti adanya hubungan antara masyarakat pemilik situs dan situs yang ada terlihat dari upaya penjagaan situs oleh keturunan langsung Sunan Kalijaga. Antara makam dan masjid sampai saat ini masih dianggap sebagai satu kesatuan oleh masyarakat. Hal ini terlihat pada saat aktivitas berziarah dilakukan. Mereka akan berusaha untuk meluangkan waktu menuju masjid yang berada persis di sebelah timur makam. 
3. Nilai Ekonomi

Situs makam Sunan Kalijaga secara tidak langsung memiliki nilai ekonomi yang tinggi. Salah satu pemanfaatan dari situs ini adalah pariwisata berbasis ziarah, yang pada akhirnya akan meningkatkan perkembangan perekonomian Kelurahan Kadilangu khususnya dan Demak pada umumnya.

\section{Aliran Pengunjung}

Peziarah yang mengunjungi Situs Makam Sunan Kalijaga secara resmi masuk dari gerbang sebelah selatan. Dari gerbang ini, pengunjung melewati koridor sepanjang \pm $150 \mathrm{~m}$ dengan lebar 3,2 m. Koridor tersebut cukup ideal karena lebarnya sesuai, bagus, beratap, dan lantai berkeramik sehingga kenyamanan pengunjung terpenuhi walaupun peziarah berjalan dari dua arah yang berlawanan. Permasalahannya adalah di sepanjang koridor ini disediakan tempat untuk menjual suvenir sehingga tidak ada ruang untuk keluar dari koridor. Bahkan, di beberapa titik, beberapa penjual masuk ke koridor sehingga ruang untuk pejalan kaki terkurangi sekitar $80 \mathrm{~cm}$. Akibatnya, pada saat puncak kunjungan peziarah di bulan Ruwah (satu bulan sebelum bulan Ramadan), koridor ini

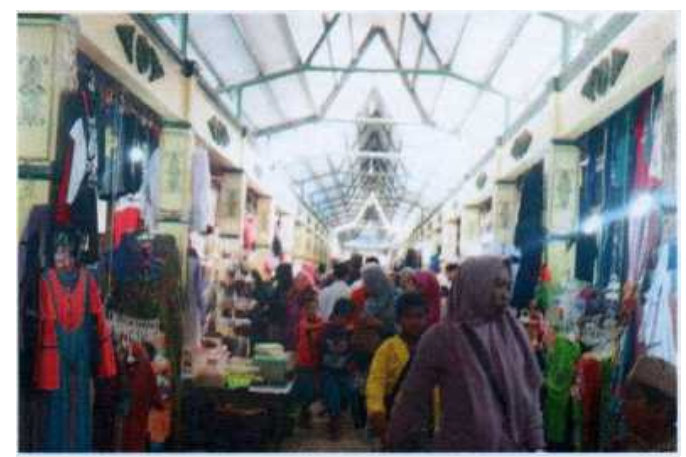

Foto 1. Koridor menuju makam Sunan Kalijaga

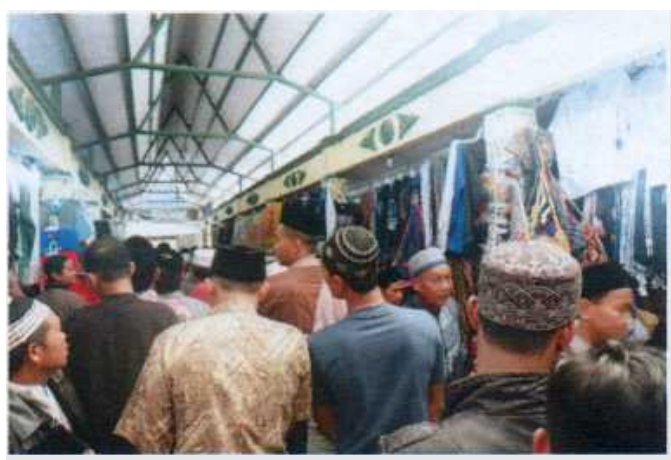

Foto 2. Simpul kemacetan peziarah dan beberapa titik koridor yang dimasuki pedagang suvenir

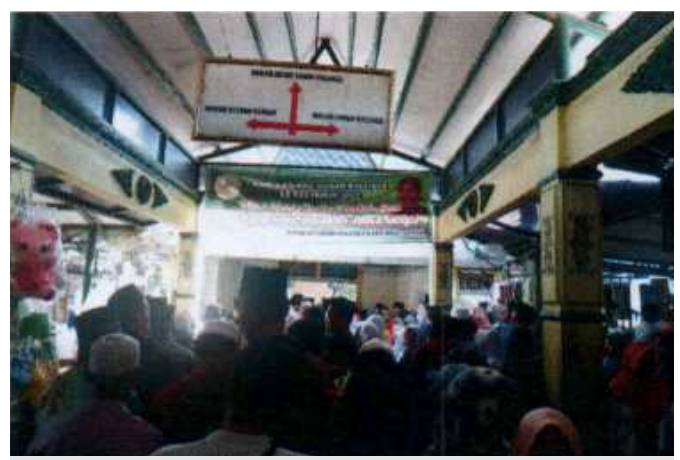

Foto 3. Kondisi eksisting alur peziarah yang masuk dan keluar situs ditunjukkan dengan tanda panah 
begitu padat oleh peziarah, bahkan sampai macet total. Kemacetan di koridor ini terjadi hanya karena ada satu pintu masuk menuju area makam dan peziarah yang masuk dan keluar, yang berjalan dengan dua arah yang berlawanan. Hal yang perlu dikhawatirkan adalah jika terjadi kondisi darurat pada saat peziarah sangat padat sehingga diperlukan upaya penyelamatan terhadap peziarah jika mengalami kendala yang sangat besar. Diperlukan solusi alternatif manajemen pengunjung yang dapat dilaksanakan mulai dari yang paling ideal hingga yang kemungkinannya paling dekat untuk dilaksanakan.

Selain koridor yang menuju arah makam Sunan Kalijaga, terdapat koridor lain yang menuju Makam Astono Gendok yang membujur barat-timur ke arah Masjid Sunan Kalijaga. Bentuk koridor ini sama dengan yang membujur utara-selatan sebagai koridor utama. Perbedaannya terletak pada lebar koridor, yaitu 2,4 m. Di sepanjang kanan-kiri koridor ini juga terdapat penjual suvenir dan makanan.

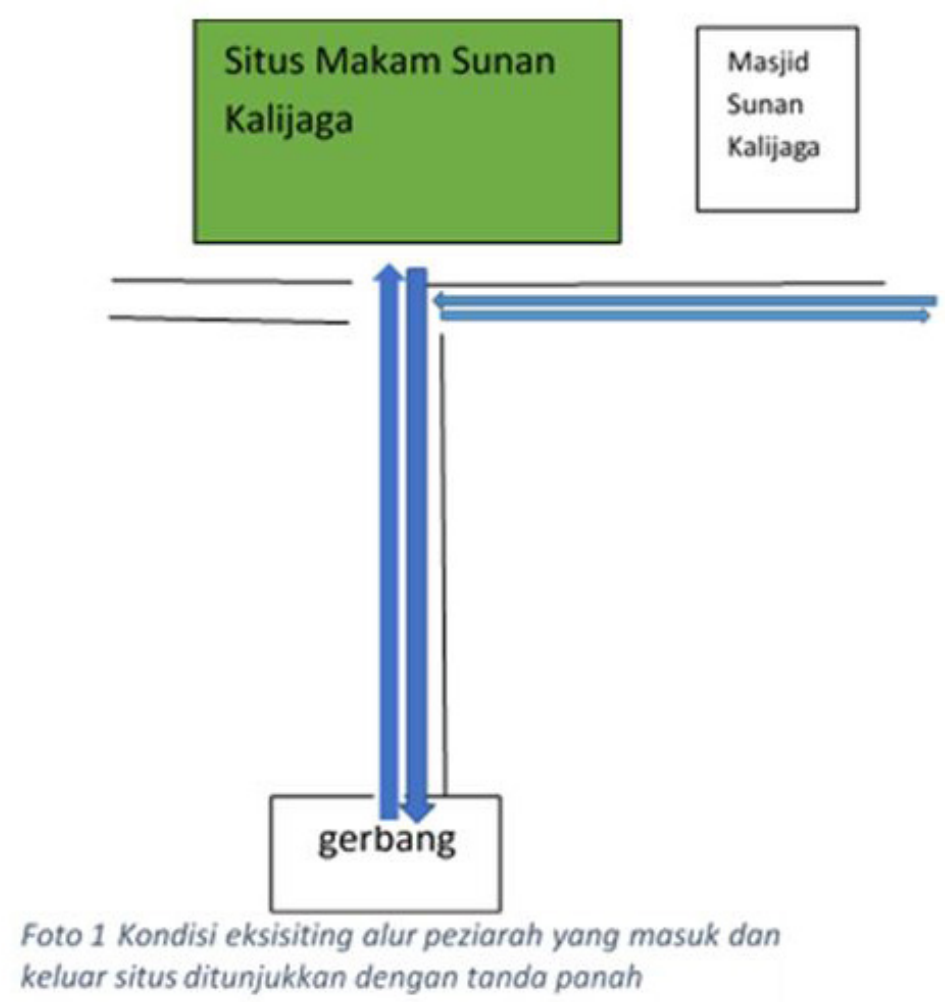

Dari kondisi eksisiting yang ada kemudian dibuat alternatif rute lain yang didesain untuk kenyamanan pengunjung, mulai dari yang paling ideal sampai mendekati kenyamanan terendah.

1. Alternatif Pertama

Pengunjung masuk melalui koridor yang sudah tersedia karena sangat memenuhi syarat. Setelah prosesi ziarah selesai, pengunjung keluar melalui pintu lain dan melewati koridor sebelah selatan masjid menuju jalan di sisi timur masjid, kemudian menuju arah selatan sampai ke telaga kuno dan menuju jalan ke parkiran kendaraan. 


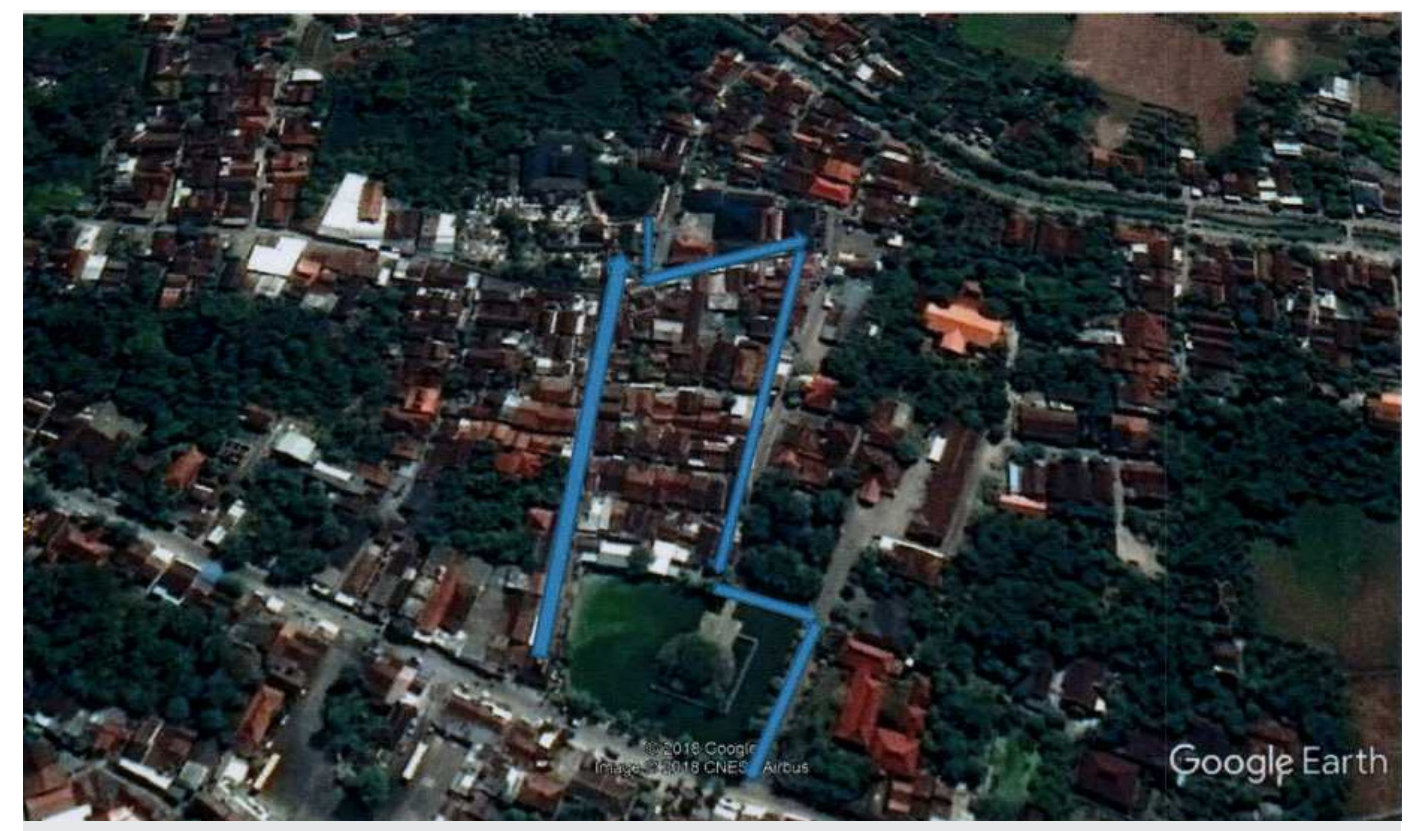

Foto 4. Alternatif pertama jalur peziarah

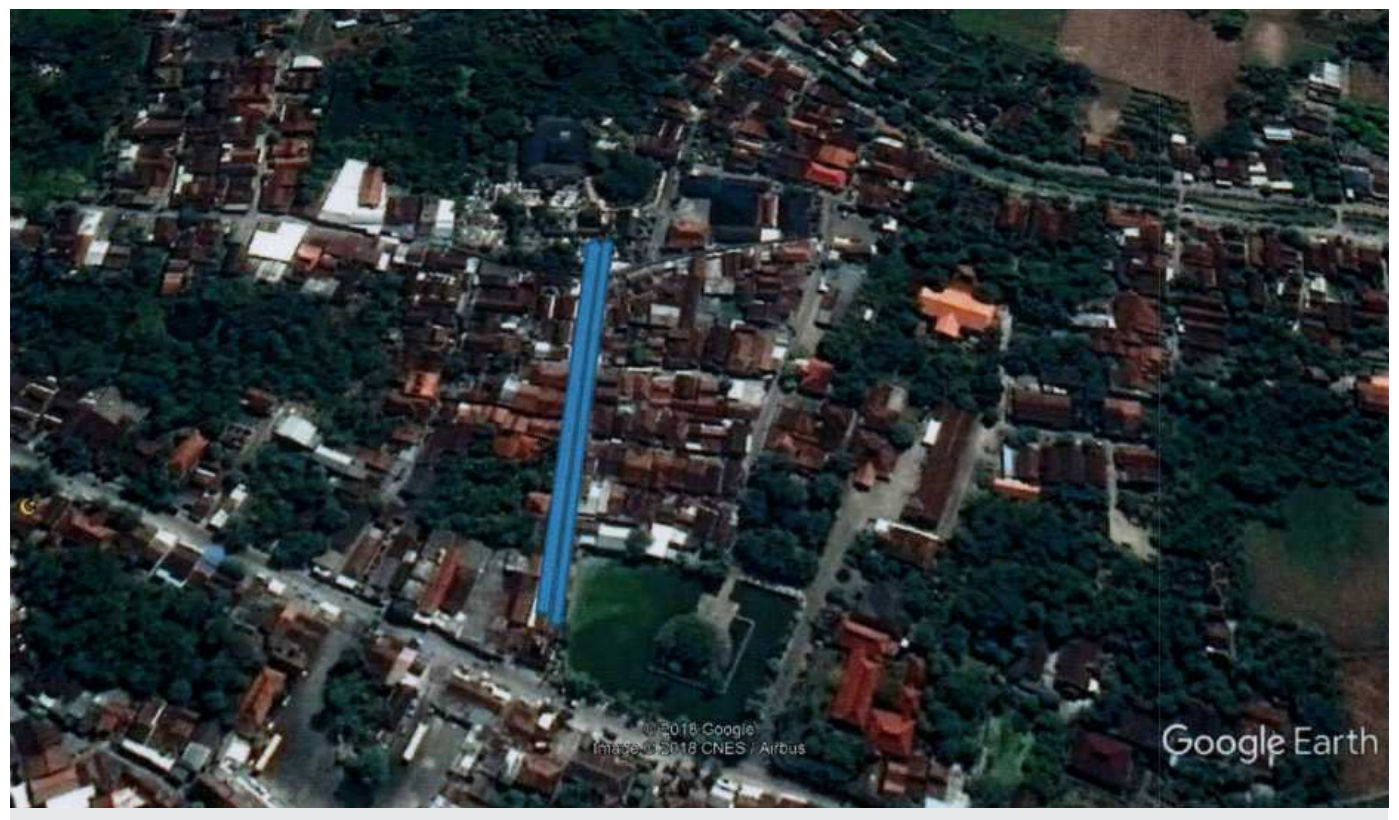

Foto 5. Altrnatif kedua jalur peziarah 
Alternatif ini sangat mendukung kenyamanan dan keamanan peziarah. Kemacetan peziarah masuk ke lokasi makam sangat kecil. Alternatif ini akan sangat terdukung jika pedagang di sepanjang koridor direlokasi ke tempat lain sehingga kekhusyukan peziarah semakin terjamin dan nilai situs makam sebagai makam wali dapat terjaga.

2. Alternatif Kedua

Peziarah melewati koridor yang ada untuk masuk dan keluar, tetapi dengan pemisahan koridor menjadi dua secara tegas dan pengaturan yang sangat ketat. Artinya, peziarah tidak diperkenankan masuk pada jalur yang salah dan ada pengaturan pembatasan jumlah yang masuk pada waktu kepadatan tinggi. Dengan demikian, harus ada petugas di pintu masuk koridor awal dan pintu masuk ke area makam yang selalu berkomunikasi untuk membuka dan menutup jumlah yang masuk.

\section{Kesimpulan}

Dari kondisi eksisiting dan kemungkinan yang akan terjadi pada masa mendatang, diperlukan adanya kegiatan rencana aksi (action plan) yang menyeluruh terhadap pengelolaan situs Makam Sunan Kalijaga beserta situs-situs di sekitarnya. Dengan demikian, dari segi kelestarian, kawasan situs tetap terjaga dan pengunjung/peziarah pun memperoleh kenyamanan dan keamanan dalam melakukan aktivitasnya. Aksi yang mendesak adalah dilakukannya penataan ulang terhadap arus pengunjung. Program pengabdian ini mencoba menghadirkan dua alternatif penataan ulang rute pengunjung agar fungsi pelestarian dan kenyamanan pengunjung dapat berjalan berdampingan.

\section{Daftar Pustaka}

Handayani, Titi dkk. 2009. Panduan Pelestarian Bangunan Warisan Budaya. Yogyakarta: Dinas Pariwisata dan Kebudayaan Kota Yogyakarta.

Sunyoto, Agus. 2014. Atlas Wali Songo Buku Pertama yang Mengungkap Wali Songo sebagai Fakta Sejarah. Jakarta: Pustaka Iman.

Tim Peneliti. 2000. Pengembangan Pelestarian Kawasan Kota Tua. Bandung: Departemen Pekerjaan Umum Badan Penelitian dan Pengembangan PU. 